\title{
REVIEW
}

\section{Regulation of the G1 phase of the mammalian cell cycle}

\author{
Donjerkovic Dubravka, David W ScotT \\ Department of Immunology, Holland Laboratory for the Bio- \\ medical Sciences, American Red Cross, 15601 Crabbs Branch \\ Way, Rockville, $M D$
}

\begin{abstract}
In any multi-cellular organism, the balance between cell division and cell death maintains a constant cell number. Both cell division cycle and cell death are highly regulated events. Whether the cell will proceed through the cycle or not, depends upon whether the conditions required at the checkpoints during the cycle are fulfilled. In higher eucaryotic cells, such as mammalian cells, signals that arrest the cycle usually act at a $\mathrm{G} 1$ checkpoint. Cells that pass this restriction point are committed to complete the cycle. Regulation of the G1 phase of the cell cycle is extremely complex and involves many different families of proteins such as retinoblastoma family, cyclin dependent kinases, cyclins, and cyclin kinase inhibitors.
\end{abstract}

Key words: Cell cycle, cyclin dependent kinase, cyclin, cyclin kinase inhibitor.

\section{Retinoblastoma family of proteins}

The retinoblastoma family consists of three members: $\mathrm{pRb}, \mathrm{p} 107$, and $\mathrm{p} 130$, that are all important in the cell cycle regulation. Studies from knockout mice showed that $\mathrm{pRb}$ null mutation is embryonically lethal, while p107 or p130 knockout mice have no known

* Corresponding author.

Tel: (301) 517-0355; Fax: (301) 517-0344; E-mail: scottd@usa.redcross.org

Abbreviations used in this paper: pRb,retinoblastoma protein; CDK, cyclin dependent kinase; CKI, cyclin kinase inhibitor; IgM, immunoglobulin M; BCR, B cell receptor; BHFR, dihydrofolate reductase; TGF- $\beta$, transforming growyh factor $\beta$. 
G1 phase of the mammalian cell cycle

abnormalities. pRb is a $105-110 \mathrm{kD}$ nuclear phosphoprotein that can be phosphorylated by $\mathrm{CDK} /$ cyclin complexes on multiple serine and threonine residues (reviewed in[1]) and acts as a tumor suppressor when in an active, hypophosphorylated form (reviewed in[2],[3]). Hypophosphorylated pRb binds E2F transcription factor. After binding to $\mathrm{E} 2 \mathrm{~F}, \mathrm{pRb}$ also recruits histone deacetylase to the promoters of E2F-regulated genes[46]. Deacetylation of the core histones results in a more compact chromatin structure that does not allow the transcription machinery to bind to the promoter and the transcription of the E2F-regulated genes is turned off (reviewed in[7]).

E2F has been shown to activate transcription of several genes whose products are important for entering the $\mathrm{S}$ phase and for DNA replication, such as genes for: $\mathrm{E} 2 \mathrm{~F}$ proteins, DP-1, pRb, p107, B-myb, PCNA, topo 1, dihydrofolate reductase (DHFR), cMyc, DNA polymerase a, thymidylate kinase, cyclin D1, cyclin A[8], cyclin E[8],[9], p21 ${ }^{\text {Cip1 }}$ [10], Cdk2[11], Cdc2, and Cdc25C. E2F can activate transcription of these genes only when free; when bound to $\mathrm{pRb}, \mathrm{E} 2 \mathrm{~F}$ is inactive[12]. Lees et al[13] showed that $\mathrm{pRb}$ binds to a whole family of E2F transcription factors. So far, known members of the E2F family are: E2F-1, E2F-2, E2F-3, E2F-4 and E2F-5. All these proteins are able to activate transcription of E2F responsive genes. Furthermore, they all heterodimerize with either DP1 or DP2 protein and these heterodimers create active E2F protein (reviewed in[14]).

The status of $\mathrm{pRb}$ phosphorylation (determined by the CDK activity) is important for the status of E2F activity because only the hypophosphorylated form of $\mathrm{pRb}$ is associated with $\mathrm{E} 2 \mathrm{~F}$. In other words, $\mathrm{pRb}$ has a growth suppressive role (is active) only when hypophosphorylated[15]. In the resting G0 cells, as well as in early G1 cells, pRb is hypophosphorylated and therefore, active[16-18]. In mid to late G1 phase of the cell cycle, $\mathrm{pRb}$ is phosphorylated by CDKs, it becomes hyperphosphorylated and therefore becomes inactive until $\mathrm{M}$ phase when it is dephosphorylated by PP1-type phosphatase [19], (Fig 1).

\section{Early G1 phase CDK/cyclin complexes}

CDKs are serine/threonine kinases that can phosphorylate multiple substrates (such as pRb family members, p53, E2F, B-myb, other CDKs, Cdc25A phosphatase, p27 Kip1 CKI, etc.) and in doing so, they can either activate or inactivate their substrates (reviewed in[20]). The catalytic activity of CDKs is controlled by four highly conserved biochemical mechanisms (reviewed in[21]), as illustrated in Fig 2. These mechanisms include: 1) activation by binding the regulatory subunits called cyclins, proteins that are cyclically synthesized and degraded throughout the cell cycle (reviewed in[22]); 2) activation by phosphorylation on threonine residue (reviewed in[23]); 3) inactivation by phosphorylation on threonine and tyrosine residues (reviewed in[23]); and 4) inactivation by binding of the inhibitory subunit called cyclin kinase inhibitor (CKI), proteins that inhibit kinase activity when present in excess in $\mathrm{CDK} /$ cyclin complexes 
(reviewed in[24]). Thus, in order to be active, CDK has to be appropriately phosphorylated, it has to be in complex with its accompanying cyclin, and must not be in complex with the CKI (more precisely, the ratio of CKI:CDK in the complex has to be low).

Different CDK/cyclin complexes phosphorylate $\mathrm{pRb}$ in different phases of the cell cycle. In early to mid G1 phase, Cdk4/cyclin D and Cdk6/cyclin D complexes are responsible for $\mathrm{pRb}$ phosphorylation (reviewed in[25]). There are three D-type cyclins (D1, D2 and D3, reviewed in[26]) that physically interact with $\mathrm{pRb}$ and inactivate it[27],[28]. They assemble into holoenzymes with either Cdk4 or Cdk6. D-type cyclins have a very short half-life ( $\sim 30 \mathrm{~min}$ ), and their expression is growth factor inducible[29]. D-type cyclin synthesis begins during the G0 to G1 transition, and they are synthesized as long as growth factor stimulation persists. D-type cyclins reach their peak level (in concentration) at late G1 phase (near the G1-S boundary). As soon as mitogens are withdrawn, D-type cyclins are degraded very rapidly. If their degradation occurs during G1 phase, cells will not enter S phase. If it occurs later in the cycle, it has no effect on the cell cycle progression.

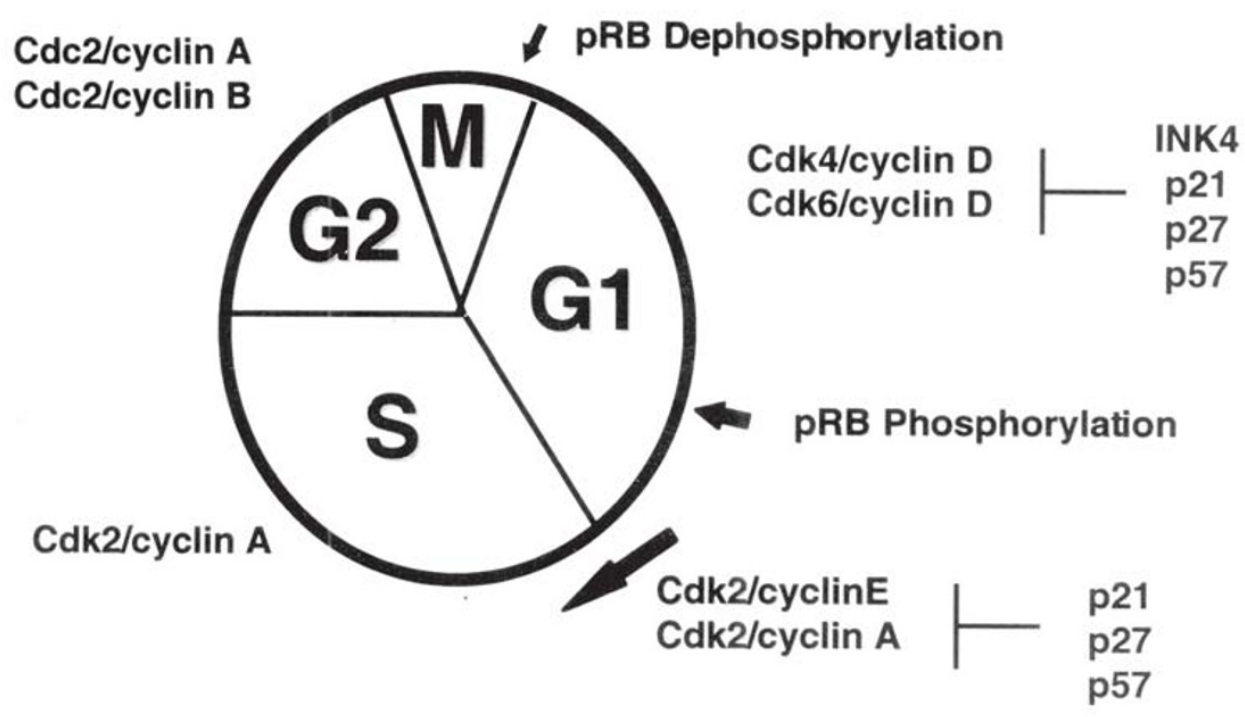

Fig 1.

Regulation of the mammalian cell cycle.

The mammalian cell cycle is regulated by the pRb family of nuclear phosphoproteins that can be phosphorylated on multiple serine and threonine residues. Hypophosphorylated pRb proteins are growth suppressors. Cdk4/cyclin D complexes phosphorylate pRb in mid G1, while Cdk2/cyclin A and Cdk2/cyclin E phosphorylate $\mathrm{pRb}$ at the G1 to $\mathrm{S}$ transition. During S phase, Cdk2/cyclin A complex is active, while in G2 phase, Cdc2/cyclin A and Cdc2/cyclin B complexes have catalytic activity. An excess of CKIs in CDK/cyclin complexes inactivates these complexes which results in growth arrest. 
G1 phase of the mammalian cell cycle

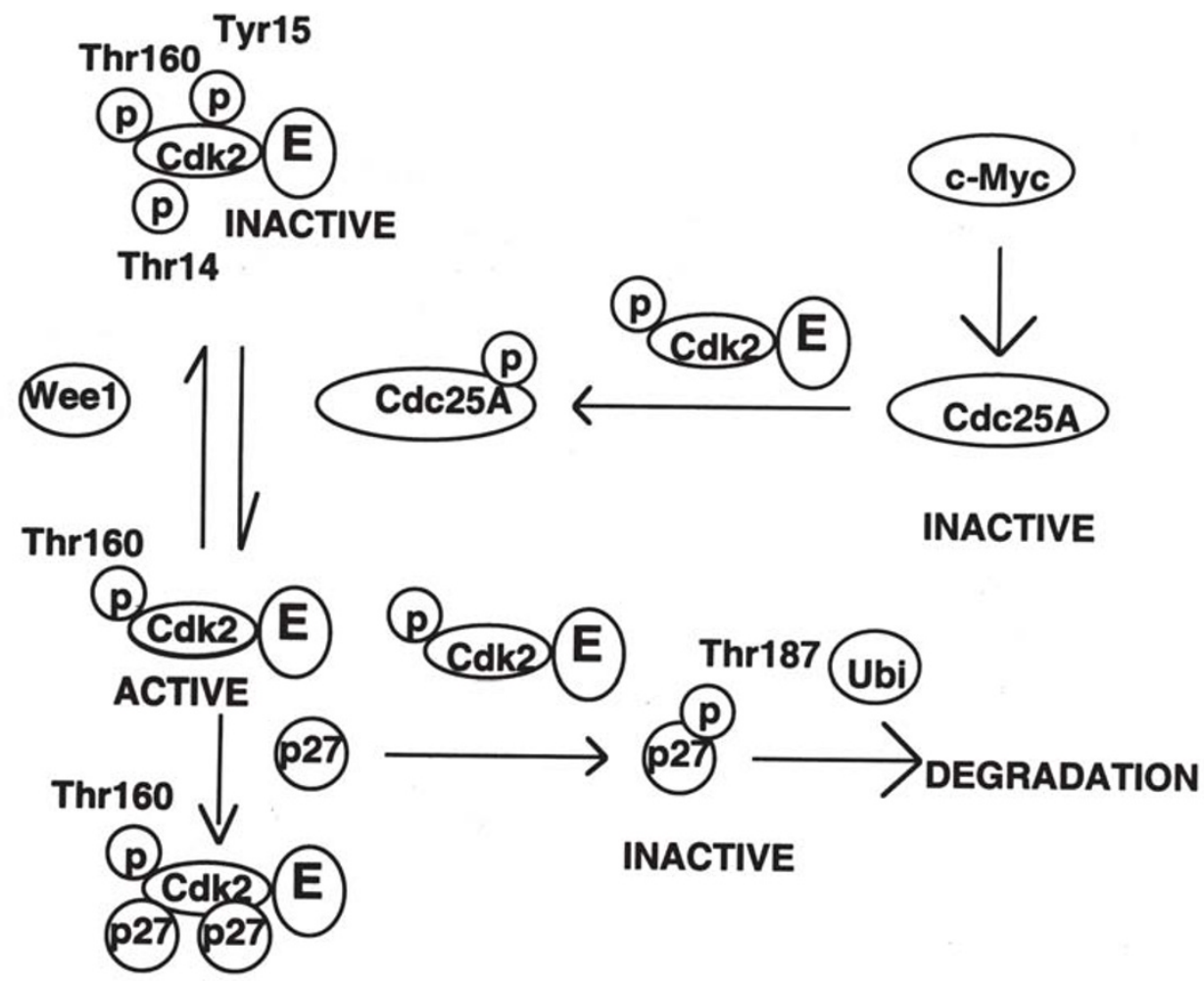

INACTIVE

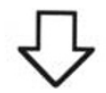

\section{LATE G1 GROWTH ARREST}

Fig 2.

Regulation of Cdk2/cyclin E kinase activity.

In order to be active, Cdk2 has to be appropriately phosphorylated and complexed with the regulatory subunit, cyclin E. Phosphorylation of Cdk2 on Thr 14 and Tyr 15 by Wee1 kinase inactivates the complex, while dephosphorylation of these residues by Cdc25A phosphatase activates the Cdk2/cyclin E complex. If the inhibitory subunit such as CKI $\mathrm{p} 27^{\mathrm{Kip} 1}$ is present in the $\mathrm{Cdk} 2 /$ cyclin $\mathrm{E}$ complex in excess, this complex becomes inactive. Cdk2/cyclin E activates Cdc25A (a positive regulator of Cdk2) and inactivates p27 ${ }^{\mathrm{Kip} 1}$ (a negative regulator of $\mathrm{Cdk} 2$ ) via phosphorylation. Additionally, Cdc25A is positively regulated by c-Myc on transcriptional level.

In order to be active, CDKs have to be appropriately phosphorylated. Cdk4 undergoes phosphorylation on the single threonine residue (Thr 161). The kinase responsible for this is CAK (CDK-activating kinase). It is an enzyme composed of catalytic subunit Cdk7 
and cyclin $\mathrm{H}[30]$. This phosphorylation has a stimulatory effect on the kinase activity. Phosphorylation of Thr14 and Tyr15, on the other hand, has an inhibitory effect and inactivates the kinase[31].

Additionally, Cdk4 and Cdk6 kinase activity can be modulated by the negative regulators (CKIs). These kinases can be inhibited by all known cyclin kinase inhibitors. CKIs can be divided into two families: INK4 family and Kip/Cip family.

\section{INK4 family of CKI}

INK4 proteins form a family of $15-20 \mathrm{kDa}$ proteins that have repeated, conserved, ankyrin motifs which are considered to participate in protein-protein interactions [32]. The first described member of the INK4 family is p16 (also called INK4a). p16 ${ }^{\text {INK4A }}$ inhibits Cdk4 and Cdk6 activity by binding in competition with D type cyclins. p16I ${ }^{N K 4 A}$ also inhibits phosphorylation of Cdk4 and Cdk6 on Thr161 by CAK[33]. Importantly, p16 is a well documented tumor suppressor gene that is frequently mutated in many human cancers (reviewed in[34]). INK4A locus has two overlapping genes, each regulated by its own promoter (reviewed in[35]). One promoter produces a transcript that encodes $\mathrm{p} 16^{\mathrm{INK} 4 \mathrm{~A}}$, while the other promoter produces a transcript that encodes $\mathrm{p} 19 \mathrm{ARF}$ (alternative reading frame) in mice and $\mathrm{p} 14^{A R F}$ in humans. Since the reading frames of the two transcripts are different, the amino acid sequences of the two proteins are completely unrelated. p19 ${ }^{A R F}$ has been shown to bind directly to p53 inhibitor Mdm2 and to neutralize its function, thereby promoting p53 transcriptional activity (reviewed in [36]).

Hannon and Beach[37] isolated another member of the INK4 family, p15 (also called INK4b). The sequences of $\mathrm{p} 15^{I N K 4 B}$ and $\mathrm{p} 16^{I N K 4 A}$ are $44 \%$ identical in the first 50 amino acids, and even $97 \%$ identical in the next 81 residues. p $15^{I N K 4 B}$ expression is induced approximately 30 fold in human keratinocytes, following TGF- $\beta$ treatment.

Two additional INK4 family members p18, (also called INK4C) and p19 (also called INK4D) were subsequently identified[38]. Overexpression of $\mathrm{p} 18^{I N K 4 C}$ induces cell cycle arrest and terminal differentiation in B cells[39], while overexpression of $\mathrm{p} 19^{I N K 4 D}$ in NIH3T3 cells leads to G1 growth arrest due to Cdk4/cyclin D1 inactivation. Finally, $\mathrm{p} 19^{I N K 4 D}$, as well as $\mathrm{p} 16^{I N K 4 A}$, rely on the presence of functional $\mathrm{pRb}$ to arrest the cycle, since overexpression of these two tumor suppressors does not lead to growth arrest in pRb deficient cells[40].

\section{Late G1 phase CDK/cyclin complexes}

While Cdk4 and Cdk6 in complex with D-type cyclins are responsible for the G1 progression, Cdk2 and recently identified Cdk3 in complex with E-type cyclins (reviewed in[41]) and with A-type cyclins are thought to act at the G1 to S transition (reviewed in [42]). Cdk2 and Cdk3 activities increase rapidly in mid to late G1 phase and peak close 
G1 phase of the mammalian cell cycle

to the G1 to S transition (reviewed in[43]). Both Cdk2 and Cdk3 form complexes with cyclins A and E as well as with more recently identified cyclins A1[44] and E2[45]. Furthermore, both Cdk2 and Cdk3 are inhibited by $\mathrm{p} 21^{\mathrm{Cip} 1}$ and $\mathrm{p} 27^{\mathrm{Kip} 1} \mathrm{CKI}$ [46].

Hinds et al[47] showed that constitutively expressed cyclins A and E can overcome $\mathrm{pRb}$ mediated suppression of proliferation. In cells overexpressing cyclin A or E, pRb becomes hyperphosphorylated much earlier than usual. As in the case of $\mathrm{D}$ type cyclin overexpression, overexpression of cyclin $\mathrm{E}$ accelerates entry into $\mathrm{S}$ phase[43]. Cyclin $\mathrm{E}$ dependent kinase activity is maximal at G1 to $\mathrm{S}$ transition. Once the cell enters $\mathrm{S}$ phase, cyclin $\mathrm{E}$ becomes degraded.

Cyclin A, on the other hand, binds to and activates Cdk2 in G1 to S transition as well as in S phase. It also binds to and activates Cdc2 in G2 and M phase[49]. Cyclin A and its associated kinase activity are not detected in early and mid G1. It first appears at late G1, accumulates through S and G2, and disappears at mitosis. Cyclin A expression is regulated on the transcriptional level, as shown by Henglein et al[50]. Cyclin A promoter is repressed during early to mid G1 and is activated in late G1 phase. As in the case of cyclin $\mathrm{E}$, overexpression of cyclin A accelerates phosphorylation of $\mathrm{pRb}[51]$ and promotes entry into S phase[48].

Very strong evidence for the role of cyclin $\mathrm{A} / \mathrm{Cdk} 2$ complex in $\mathrm{G} 1$ to $\mathrm{S}$ transition comes from the research conducted on B lymphoma cell lines. These cells undergo late G1 cell cycle arrest, and subsequently apoptosis, when treated with anti-immunoglobulin $\mathrm{M}$ (anti-IgM) antibody. In such anti-IgM arrested cells, most of the $\mathrm{pRb}$ is in hypophosphorylated (active) form. Joseph et al[52] showed that hypophosphorylation of $\mathrm{pRb}$ is due to the inhibition of $\mathrm{Cdk} 2 /$ cyclin A kinase activity.

Although Cdk2/cyclin E and Cdk2/cyclin A complexes are clearly involved in $\mathrm{pRb}$ phosphorylation[53], Cdk2/cyclin E also appears to have at least one additional, still unidentified, $\mathrm{pRb}$ independent role in $\mathrm{G} 1$ to $\mathrm{S}$ transition. The experimental evidence for this is as follows. Firstly, inducible expression of cyclin E in fibroblasts accelerates G1 to $\mathrm{S}$ progression without affecting the kinetics of $\mathrm{pRb}$ phosphorylation[54]. Secondly, unlike D-type cyclins, cyclin $\mathrm{E}$ is essential for cell cycle progression in $\mathrm{pRb}$-deficient cells[55]. Thirdly, ectopic expression of E2F-1 bypasses growth arrest by D-type cyclin inhibitor p16, but not by Cdk2/cyclin E inhibitor p27Kip1[56]. Fourthly, ectopic expression of cyclin $\mathrm{E}$ bypasses $\mathrm{p} 16$ - or $\mathrm{pRb}$-mediated cell cycle arrest independently of pRb phosphorylation[56],[57]. Finally, p21 ${ }^{\text {Cip1 }}$ (another CKI of Cdk2 complexes) overexpression suppresses growth and E2F activity in pRb deficient cells[58]. The identity of the $\mathrm{pRb}$ independent mechanism by which $\mathrm{Cdk} 2$ complexes promote cell growth is at present unclear.

\section{Cdc25A phosphatase}

In the case of Cdk2, its active catalytic subunit has to be phosphorylated on Thr 160 and must not be phosphorylated on Thr 14 and Tyr 15[59], (Fig 2). Cdk2 is phosphory- 
lated on Thr 160 in vitro by CAK. CAK (reviewed in[60],[61]) is a multi subunit enzyme that consists of cyclin $\mathrm{H}$ and $\mathrm{Cdk}$ [30]. Thr160 can be dephosphorylated by KAP phosphatase in the absence of cyclin, thereby rendering Cdk2 inactive even upon subsequent binding to appropriate cyclin[62]. Cdk2 is phosphorylated on Thr 14 and Tyr 15 in vitro by Wee1/Mik1 related protein kinases. Cdk2 is activated in vitro by Cdc25A, a dual specificity phosphatase that is expressed predominantly in late G1 and that dephosphorylates Tyr 15 and possibly Thr 14 residues[59]. Downregulation of Cdc25A leads to growth arrest in late G1[63]. In vitro assays show that Cdc25A activity is increased in S phase when it is phosphorylated by Cdk2/cyclin E[63], (Fig 2). cdc25A is transcriptionally regulated by c-Myc. Two functional binding sites for the c-Myc/Max heterodimer were found in the cdc25A promoter in vitro[64]. Cdc25A is negatively regulated in human keratinocytes by TGF- $\beta$ [65]. More precisely, cdc25A transcription is inhibited by E2F-4/p130 complex that recruits histone deacetylase to the E2F site of the cdc25A promoter in response to TGF- $\beta[66]$.

Finally, similar to Cdk4 and Cdk6, Cdk2 can also be negatively regulated by CKIs. However, in contrast to $\mathrm{Cdk} 4$ and $\mathrm{Cdk} 6$, which are inhibited primarily by INK4 family members, Cdk2 (and Cdk3) are inhibited by members of the Kip/Cip family of CKI (p21, $\mathrm{p} 27$, and $\mathrm{p} 57$ ).

\section{p21 $1^{\text {Cip1 }}$}

p21 is a $21 \mathrm{kDa}$ protein, also called Cip1 or Waf1, and is the first characterized member of the family[67]. Inhibition of CDK activity by p21 $1^{\text {Cip } 1}$ seems to require the binding of more than one $\mathrm{p} 21^{\text {Cipl }}$ molecule[68]. Cyclin/CDK complexes containing a single p21 $1^{\text {Cip } 1}$ molecule are still catalytically active. On the other hand, those containing multiple p21 $1^{\text {Cip } 1}$ molecules are not catalytically active. Furthermore, p21 ${ }^{\text {Cip } 1}$ (as well as $\mathrm{p} 27^{\mathrm{Kip} 1}$ ) has separate binding sites for CDK and cyclin, and both sites need to be intact in order for CKI to bind to CDK/cyclin complexes[69].

The expression of $\mathrm{p} 21^{\text {Cip } 1}$ gene is regulated by $\mathrm{p} 53$ tumor suppressor protein. $\mathrm{p} 21^{\text {Cip } 1}$ promoter has a p53 binding site[70]. However, p53 is not the only transcription factor that regulates $\mathrm{p} 21^{\text {Cip } 1}$ expression, since $\mathrm{p} 21^{\text {Cip1 } 1}$ is expressed in p53-deficient cells. Because it is regulated by $\mathrm{p} 53, \mathrm{p} 21^{\operatorname{Cip} 1}$ appears to be essential in inducing $\mathrm{p} 53$-mediated growth arrest as a response to the DNA damage. Therefore, in the cells lacking functional $\mathrm{p} 53$, the failure to induce $\mathrm{p} 21^{\text {Cip } 1}$ after DNA damage could result in elevated genetic instability (as is the case in tumor cells).

p21 Cip1 (as well as other Kip/Cip family members) are thought to inhibit Cdk2 activity by preventing Thr160 phosphorylation by CAK[33]. Recently however, a novel function for Kip/Cip family members was proposed[71]. Harlow and colleagues suggested that in addition to their roles as inhibitors, Kip/Cip family members also act as adapter proteins that assemble $\mathrm{CDK} /$ cyclin complexes and target them to the nucleus. These studies were confirmed by Cheng et al[72] who showed that Kip/Cip CDK "inhibitors" 
G1 phase of the mammalian cell cycle

are actually essential activators of $\mathrm{Cdk} 4$ and $\mathrm{Cdk} 6$. Murine fibroblasts deficient in both $\mathrm{p} 21^{\text {Cip } 1}$ and $\mathrm{p} 27^{\text {Kip } 1}$ fail to upregulate D-type cyclins upon mitogen stimulation. They also fail to assemble CDK/cyclin D complexes and to direct D-type cyclins to the nucleus. All these effects are reversed by restoring CKI function. Finally, Lees and coworkers[73] also showed that formation of Cdk4/cyclin $\mathrm{D}$ complexes is promoted by members of the Kip/Cip family of CKI. INK4 family members, on the other hand, bind Cdk4 and, in doing so, inhibit the formation of $\mathrm{Cdk} 4 /$ cyclin $\mathrm{D}$ complexes.

A current dogma is that $\mathrm{Cdk} 2 / \mathrm{cyclin} / \mathrm{p} 21^{\operatorname{Cip} 1}$ complexes can transition between active and inactive states, through the changes in the stoichiometry of $\mathrm{p} 21^{\text {Cip } 1}$ subunit in the complex[68]. Most recently, however, this dogma has been challenged by Hengst et al[74]. Using analytical ultracentrifugation of Cdk2/cyclinA/p21 ${ }^{\operatorname{Cip} 1}$ complexes, these researchers demonstrated that complete inhibition of $\mathrm{CDK} /$ cyclin complexes is achieved by one single molecule of $\mathrm{p} 21^{\text {Cip } 1}$ present in the complex. Furthermore, they showed that $\mathrm{p} 21^{\text {Cip } 1}$ saturated complexes contain only one stably bound inhibitor molecule.

\section{p27 Kip1}

$\mathrm{p} 27^{\text {Kip } 1}$ is a $27 \mathrm{kDa}$ protein that is $42 \%$ identical with $\mathrm{p} 21^{\operatorname{Cip} 1}$ at its $\mathrm{N}$-terminus[75], [76]. It has 198 aa with the cyclin binding domain residing between aa 27-43, and CDK binding domain between aa 60-79. The crystal structure of Cdk2/cyclin A/p27 Kip1 complexes[77] reveals that $\mathrm{p} 27^{K i p 1}$ binds to both cyclin A and Cdk2 and also inserts itself deep inside the catalytic cleft, mimicking ATP. Both intact cyclin and CDK binding sites are needed for the stable association of $\mathrm{p} 27^{\mathrm{Kip} 1}$ with the Cdk2/cyclin A complex. Indeed, mutants of $\mathrm{p} 27^{\text {Kip } 1}$ harboring changes in either binding domain are deficient in inducing $\mathrm{E} 2 \mathrm{~F} / \mathrm{p} 130$ accumulation and inhibition of transcription of E2F-regulated genes such as cyclin A, cyclin E and DHFR[78]. As in the case of p21 Cip1 it is thought that the stoichiometry of $\mathrm{p} 27^{\mathrm{Kip} 1}$ in $\mathrm{CDK} /$ cyclin complexes determines whether the kinase activity is inhibited or not.

p2 $7^{\text {Kip } 1}$ deficient mice display enhanced growth, multiple organ hyperplasia, retinal dysplasia, pituitary tumors and female sterility[79-81]. These mice have enlarged thymi and spleens, and an increased numbers of thymocytes and mature T cells. However, the number of B cells in these mice is normal and so are functions of B cells. In serum starved p27 ${ }^{\text {Kip } 1}$ deficient fibroblasts, Cdk2 activity is still inhibited[82]. Additionally, p2 $7^{\text {Kip } 1}$ deficient oligodendrocyte precursor cells do eventually differentiate, but they go through several more cycles before doing so, as compared to $\mathrm{p} 27^{\mathrm{Kip} 1}$ wild type cells[83]. Together, these data suggest the existence of alternative pathway(s) of Cdk2 inactivation and growth arrest when the $\mathrm{p} 27^{\text {Kip } 1}$ pathway is disabled or is missing.

Levels of $\mathrm{p} 27^{\text {Kip } 1}$ are increased in a variety of cells arrested in G1 by different stimuli, such as murine B-lymphoma cells arrested upon BCR crosslinking[84], macrophages arrested by cAMP[85], fibroblasts arrested by lovastatin[86] or by serum withdrawal [54], and Mv1Lu mink epithelial cells arrested by TGF- $\beta$ [87],[88]. 
$\mathrm{p} 27^{\text {Kip } 1}$ regulation seems to differ slightly from one cell type to another. $\mathrm{p} 27^{\text {Kip } 1}$ seems to be predominantly regulated on the protein level. Redistribution of $\mathrm{p} 27^{\text {Kip } 1}$ among different $\mathrm{CDK} /$ cyclin complexes is one way of regulating this CKI. In some systems, the availability of $\mathrm{p} 27^{\text {Kip } 1}$ (and $\mathrm{p} 21^{\text {Cip } 1}$ ) depends on their subcellular localization. For example, in normal anchorage-dependent fibroblasts, detachment of the cells results in accumulation of the Cdk2/cyclin E/p27 Kip1 complexes in the nucleus[89]. In contrast, in anchorage-independent, transformed fibroblasts, $\mathrm{p} 21^{\operatorname{Cip} 1}$ and $\mathrm{p} 27^{\mathrm{Kip} 1}$ are sequestered away from the nucleus by cytoplasmic CDK/cyclin complexes. Another interesting mechanism of posttranscriptional regulation of $\mathrm{p} 27^{\text {Kip } 1}$ was reported by Millard et al[90]. In human leukemic HL-60 cells arrested with phorbol ester PMA, p27 ${ }^{\text {Kip } 1}$ accumulation is due to an increase in the amount of $\mathrm{p} 27^{\text {Kip } 1} \mathrm{mRNA}$ in polyribosomes, which results in an increased translation rate. An increased translation rate of $\mathrm{p} 27^{K i p 1}$ has also been reported in lovastatin-arrested HeLa cells as well as in density-arrested fibroblasts[91]. In this same experimental system, a decreased rate of $\mathrm{p} 27^{K i p 1}$ degradation was observed. Indeed, regulation of $\mathrm{p} 27^{\text {Kip } 1}$ protein degradation seems to be the most important mechanism by which this important CKI is regulated. It is known that $\mathrm{p} 27^{\text {Kip } 1}$ degradation occurs via ubiquitination ([92]; reviewed in[93]), because p27 $7^{\text {Kip } 1}$ is phosphorylated on Thr 187 by Cdk2/cyclin $\mathrm{E}$ and this phosphorylated form is then targeted for ubiquitination and degradation[94-97]. Pagano and coworkers[98] demonstrated that ubiquitination of $\mathrm{p} 27^{\text {Kip } 1}$ requires prior phosphorylation of $\mathrm{p} 27^{\mathrm{Kip} 1}$ on Thr187 as well as trimeric complex formation among $\mathrm{p} 27^{\mathrm{Kip} 1}$, Cdk2 and cyclin A or E. As expected, proteasome inhibitors lead to $\mathrm{p} 27^{\text {Kip } 1}$ accumulation[99]. $\mathrm{p} 27^{\text {Kip } 1}$ ubiquitination and degradation seems to be restricted to the cytoplasmic compartment (reviewed in [100]). Tomoda et al[101] reported a novel protein Jab1 that binds $\mathrm{p} 27^{\text {Kip } 1}$ in the nucleus and shuttles it to the cytoplasm where it becomes ubiquitinated and degraded. Although ubiquitin-mediated proteolysis is a major mean of $\mathrm{p} 27^{\text {Kip } 1}$ degradation, most recent findings argue that this is not the only mean of p27 $7^{\text {Kip } 1}$ degradation. Levkau et al[102] reported the C-terminal cleavage of both p21Cip1 and $\mathrm{p} 27^{\text {Kip } 1}$ by caspase 3 and caspase 7 in human umbilical vein endothelial cells (HUVECs) undergoing growth factor deprivation-induced apoptosis. Additionally, it seems that $\mathrm{Cdk} 2$ is not the only kinase that can phosphorylate p27 ${ }^{\text {Kip }}$. Kawada et al [103] found that $\mathrm{p} 27^{\text {Kip } 1}$ can be phosphorylated by Ras/Raf-induced MAP kinase in vitro and that such phosphorylated $\mathrm{p} 27^{\text {Kip } 1}$ is unable to bind to and inhibit Cdk2.

There are several lines of evidence that suggest c-Myc as a negative regulator of $\mathrm{p} 27^{\text {Kip } 1}$. For example, induction of c-MycER fusion protein by 4-OH tamoxifen in Rat1 fibroblasts leads to Cdk2/cyclin E activation. This is a result of: i) inhibition of $\mathrm{p} 27^{\text {Kip } 1}$ binding to the Cdk2/cyclin E complexes[104], ii) p2 $7^{\text {Kip } 1}$ release from the Cdk2/cyclin E complexes[97], and iii) p27 $7^{\text {Kip } 1}$ degradation[105]. Furthermore, retroviral expression of p27 Kip 1 induces G1 arrest in parental Rat1 cells, but not in Rat1 cells that ectopically express c-Myc[106]. Additionally, co-expression of Ras and c-Myc leads to cyclin Eassociated kinase activity, S phase induction and, mostly important, p27 ${ }^{\text {Kip } 1} \operatorname{loss}[107]$. In several experimental systems, there is an inverse correlation between c-Myc and 
G1 phase of the mammalian cell cycle

p27 ${ }^{\text {Kip } 1}$ expression. For example, there is a correlation between c-Myc overexpression and $\mathrm{p} 27^{\text {Kip } 1}$ downregulation in mammary epithelial cells[108], while there is an increased p27Kip1 expression in Rat1 cells deficient in c-Myc[109]. There is also an experimental evidence that c-Myc negatively regulates $\mathrm{p} 27^{\text {Kip } 1}$ in lymphocytes. IL-2 induces c-Myc in T cells[110] and complete stimulation of T cells (TCR engagement and IL-2R engagement) downregulates p27 Kip1 [111]. In B cells, mIgM crosslinking induces c-Myc[112] and complete stimulation of B cells (BCR engagement and CD40 engagement) downregulates p2 $7^{\text {Kip } 1}[113]$.

In murine B- lymphoma cells, there is also an inverse correlation between c-Myc and $\mathrm{p} 27^{\text {Kip } 1}$ levels. The decrease in c-Myc strongly correlates with anti-IgM induced p27 ${ }^{\text {Kip } 1}$ accumulation, late G1 arrest and apoptosis in anti-IgM sensitive murine Blymphoma cells. In this experimental system, the loss of c-Myc, when accompanied by an increase in cytosolic free calcium, both of which are induced by mIgM crosslinking, is able to induce $\mathrm{p} 27^{\text {Kipl }}$ accumulation, growth arrest and apoptosis[114].

Because of its growth inhibitory effects via Cdk2 inhibition, p27 ${ }^{\text {Kip } 1}$ is a potential candidate tumor suppressor protein. Abnormally low levels of $\mathrm{p} 27^{\text {Kip } 1}$ protein are frequently found in many human cancers, and these low levels correlate with the aggressiveness of the tumor and with the high mortality rate of the patients. However, it has not been possible to establish a causal link between p27 Kip 1 and tumor suppression because only rare instances of homozygous inactivating mutations of $\mathrm{p} 27^{\text {Kip } 1}$ gene have been found in human tumors. Fero et al[115] showed that p27 Kip1-/ mice and p27 Kip1+/- mice are predisposed to tumors in multiple tissues when challenged with g-irradiation or chemical carcinogens. However, the remaining wild-type allele in $\mathrm{p} 27^{\mathrm{Kip1+/}}$ mice is neither mutated nor silenced. Therefore, $\mathrm{p} 27^{\text {Kip } 1}$ is a multiple tissue tumor suppressor in mice, but it is haplo-insufficient for tumor suppression.

In recent years a large number of studies implicated p27 $7^{\text {Kip } 1}$, as well as other CKIs, as a prognostic factor in various human cancers (reviewed in[116],[117]). For example, $\mathrm{p} 27^{\text {Kip } 1}$ is a prognostic marker in breast and colorectal cancer[118], as well as in prostate adenocarcinoma[119].

\section{p57 ${ }^{\text {Kip2 }}$}

Finally, p57 (also called Kip2) is the most recently discovered Kip/Cip family member [120]. It is structurally the most complex member of the family. p57 ${ }^{\text {Kip } 2}$ deficient mice have altered cell differentiation and proliferation. They have many phenotypic characteristics seen in Beckwith-Wiedemann syndrome, a pleiotropic hereditary disorder that is characterized by overgrowth and predisposition to cancer, and that is associated with translocations in p57 gene[121]. Unlike p27 $7^{\text {Kip } 1}, \mathrm{p} 21^{\text {Cip } 1}$, and $\mathrm{p} 18^{I N K 4 C}$ CKIs which are not imprinted, (i.e. biallelic expression is observed in both fetal and adult tissues [122]), p57 ${ }^{K i p 2}$ is normally imprinted with the preferential expression of the maternal allele. 


\section{CONCLUSION}

Regulation of the cell cycle in eucaryotic cells is very complex and is conserved among species, from yeast to humans. Over the last decade, our understanding of the mammalian cell cycle regulation increased dramatically. The discovery of the important cell cycle regulators such as the $\mathrm{pRb}$ family of proteins, CDKs, cyclins, CKIs, etc. provides the potential for novel therapeutic targets in treatment of diseases where the balance between cell proliferation and cell death is disrupted.

\section{ACKNOWLEDGMENTS}

The authors thank Ms. Hao Nguyen for a critical reading of the manuscript. This work was supported by USPHS grant CA55644.

\section{REFERENCES}

[1] Taya Y. RB kinases and RB-binding proteins: new points of view. Trends Biochem Sci 1997; 22:14-7.

[2] Nevins JR, Leone G, DeGregori J et al. Role of the Rb/E2F pathway in cell growth control. J Cell Physiol 1997; 173:233-6.

[3] Herwig S, Strauss M. The retinoblastoma protein: a master regulator of cell cycle, differentiation and apoptosis. Eur J Biochem 1997; 246:581-601.

[4] Brehm A, Miska EA, McCance DJ et al. Retinoblastoma protein recruits histone deacetylase to repress transcription [see comments]. Nature 1998; 391:597-601.

[5] Magnaghi Jaulin L, Groisman R, Naguibneva I et al. Retinoblastoma protein represses transcription by recruiting a histone deacetylase [see comments]. Nature 1998; 391:601-5.

[6] Luo RX, Postigo AA, Dean DC. Rb interacts with histone deacetylase to repress transcription. Cell 1998; 92:463-73.

[7] DePinho RA. Transcriptional repression. The cancer-chromatin connection [news; comment]. Nature 1998; 391:533, 5-6.

[8] Soucek T, Pusch O, Hengstschlager Ottnad E et al. Deregulated expression of E2F-1 induces cyclin Aand E- associated kinase activities independently from cell cycle position. Oncogene 1997; 14:2251-7.

[9] Geng Y, Eaton EN, Picon M et al. Regulation of cyclin E transcription by E2Fs and retinoblastoma protein. Oncogene 1996; 12:1173-80.

[10] Hiyama H, Iavarone A, LaBaer J et al. Regulated ectopic expression of cyclin D1 induces transcriptional activation of the cdk inhibitor p21 gene without altering cell cycle progression. Oncogene 1997; 14:253342.

[11] Leone G, DeGregori J, Yan Z et al. E2F3 activity is regulated during the cell cycle and is required for the induction of S phase. Genes Dev 1998; 12:2120-30.

[12] Helin K, Harlow E, Fattaey A. Inhibition of E2F-1 transactivation by direct binding of the retinoblastoma protein. Mol Cell Biol 1993; 13:6501-8.

[13] Lees JA, Saito M, Vidal M et al. The retinoblastoma protein binds to a family of E2F transcription factors. Mol Cell Biol 1993; 13:7813-25.

[14] La Thangue NB. DRTF1/E2F: an expanding family of heterodimeric transcription factors implicated in cell-cycle control. Trends Biochem Sci 1994; 19:108-14.

[15] Nevins JR, Chellappan SP, Mudryj M et al. E2F transcription factor is a target for the RB protein and the cyclin A protein. Cold Spring Harb Symp Quant Biol 1991; 56:157-62.

[16] Mihara K, Cao XR, Yen A et al. Cell cycle-dependent regulation of phosphorylation of the human 
G1 phase of the mammalian cell cycle

retinoblastoma gene product. Science 1989; 246:1300-3.

[17] DeCaprio JA, Ludlow JW, Lynch D et al. The product of the retinoblastoma susceptibility gene has properties of a cell cycle regulatory element. Cell 1989; 58:1085-95.

[18] Buchkovich K, Duffy LA, Harlow E. The retinoblastoma protein is phosphorylated during specific phases of the cell cycle. Cell 1989; 58:1097-105.

[19] Ludlow JW, Glendening CL, Livingston DM et al. Specific enzymatic dephosphorylation of the retinoblastoma protein. Mol Cell Biol 1993; 13:367-72.

[20] Dynlacht BD. Regulation of transcription by proteins that control the cell cycle. Nature 1997; 389:14952.

[21] Morgan DO. Principles of CDK regulation. Nature 1995; 374 :131-4.

[22] Morgan DO. The dynamics of cyclin dependent kinase structure. Curr Opin Cell Biol 1996; 8:767-72.

[23] Morgan DO, Fisher RP, Espinoza FH et al. Control of eukaryotic cell cycle progression by phosphorylation of cyclin-dependent kinases. Cancer J Sci Am 1998; 4 Suppl 1:S77-83.

[24] Harper JW. Cyclin dependent kinase inhibitors. Cancer Surv 1997; 29:91-107.

[25] Sherr CJ, Kato J, Quelle DE et al. D-type cyclins and their cyclin-dependent kinases: G1 phase integrators of the mitogenic response. Cold Spring Harb Symp Quant Biol 1994; 59:11-9.

[26] Sherr CJ, Roberts JM. Inhibitors of mammalian G1 cyclin -dependent kinases. Genes Dev 1995; 9:114963.

[27] Dowdy SF, Hinds PW, Louie K et al. Physical interaction of the retinoblastoma protein with human D cyclins. Cell 1993; 73:499-511.

[28] Ewen ME, Sluss HK, Sherr CJ et al. Functional interactions of the retinoblastoma protein with mammalian D-type cyclins. Cell 1993; 73:487-97.

[29] Matsushime H, Roussel MF, Ashmun RA et al. Colony-stimulating factor 1 regulates novel cyclins during the G1 phase of the cell cycle. Cell 1991; 65:701-13.

[30] Makela TP, Tassan JP, Nigg EA et al. A cyclin associated with the CDK-activating kinase MO15. Nature 1994; 371:254-7.

[31] Terada Y, Tatsuka M, Jinno S et al. Requirement for tyrosine phosphorylation of Cdk4 in G1 arrest induced by ultraviolet irradiation. Nature 1995; 376:358-62.

[32] Serrano M, Hannon GJ, Beach D. A new regulatory motif in cell-cycle control causing specific inhibition of cyclin D/CDK4 [see comments]. Nature 1993; 366:704-7.

[33][1] Aprelikova O, Xiong Y, Liu ET. Both p16 and p21 families of cyclin-dependent kinase (CDK) inhibitors block the phosphorylation of cyclin-dependent kinases by the CDK- activating kinase. J Biol Chem 1995; 270:18195-7.

[34] Serrano M. The tumor suppressor protein p16INK4a. Exp Cell Res 1997; 237:7-13.

[35] Larsen CJ. p16INK4a: a gene with a dual capacity to encode unrelated proteins that inhibit cell cycle progression. Oncogene 1996; 12:2041-4.

[36] Sherr CJ. Tumor surveillance via the ARF-p53 pathway. Genes Dev 1998; 12:2984-91.

[37] Hannon GJ, Beach D. p15INK4B is a potential effector of TGF-beta-induced cell cycle arrest [see comments]. Nature 1994; 371:257-61.

[38] Hirai H, Roussel MF, Kato JY et al. Novel INK4 proteins, p19 and p18, are specific inhibitors of the cyclin D-dependent kinases CDK4 and CDK6. Mol Cell Biol 1995; 15:2672-81.

[39] Morse L, Chen D, Franklin D et al. Induction of cell cycle arrest and B cell terminal differentiation by CDK inhibitor p18 (INK4c) and IL-6. Immunity 1997; 6:47-56.

[40] Guan KL, Jenkins CW, Li Y et al. Growth suppression by p18, a p16INK4/MTS1- and p14INK4B/MTS2related CDK6 inhibitor, correlates with wild-type pRb function. Genes Dev 1994; 8:2939-52.

[41] Reed SI. Cyclin E: in mid-cycle. Biochim Biophys Acta 1996; 1287:151-3.

[42] Reed SI. Control of the G1/S transition. Cancer Surv 1997; 29:7-23.

[43] Hengstschlager M, Braun K, Soucek T et al. Cyclin-dependent kinases at the G1-S transition of the mammalian cell cycle. Mutat Res 1999; 436:1-9. 


\section{Donjerkovic D and DW Scott}

[44] Yang R, Morosetti R, Koeffler HP. Characterization of a second human cyclin A that is highly expressed in testis and in several leukemic cell lines. Cancer Res 1997; 57:913-20.

[45] Lauper N, Beck AR, Cariou S et al. Cyclin E2: a novel CDK2 partner in the late G1 and S phases of the mammalian cell cycle. Oncogene 1998; 17:2637-43.

[46] Braun K, Holzl G, Soucek T et al. Investigation of the cell cycle regulation of cdk3-associated kinase activity and the role of cdk3 in proliferation and transformation. Oncogene 1998; 17:2259-69.

[47] Hinds PW, Mittnacht S, Dulic V et al. Regulation of retinoblastoma protein functions by ectopic expression of human cyclins. Cell 1992; 70:993-1006.

[48] Resnitzky D, Gossen M, Bujard H et al. Acceleration of the G1/S phase transition by expression of cyclins D1 and E with an inducible system. Mol Cell Biol 1994; 14:1669-79.

[49] Pagano M, Pepperkok R, Verde F et al. Cyclin A is required at two points in the human cell cycle. Embo J 1992; 11:961-71.

[50] Henglein B, Chenivesse X, Wang J et al. Structure and cell cycle-regulated transcription of the human cyclin A gene. Proc Natl Acad Sci U S A 1994; 91:5490-4.

[51] Rosenberg AR, Zindy F, Le Deist F et al. Overexpression of human cyclin A advances entry into S phase. Oncogene 1995; 10:1501-9.

[52] Joseph LF, Ezhevsky S, Scott DW. Lymphoma models for B-cell activation and tolerance: antiimmunoglobulin $\mathrm{M}$ treatment induces growth arrest by preventing the formation of an active kinase complex which phosphorylates retinoblastoma gene product in G1. Cell Growth Differ 1995; 6:51-7.

[53] Dynlacht BD, Flores O, Lees JA et al. Differential regulation of E2F transactivation by cyclin/cdk2 complexes. Genes Dev 1994; 8:1772-86.

[54] Resnitzky D, Reed SI. Different roles for cyclins D1 and E in regulation of the G1-to-S transition. Mol Cell Biol 1995; 15:3463-9.

[55] Ohtsubo M, Theodoras AM, Schumacher J et al. Human cyclin E, a nuclear protein essential for the G1-to-S phase transition. Mol Cell Biol 1995; 15:2612-24.

[56] Alevizopoulos K, Vlach J, Hennecke S et al. Cyclin E and c-Myc promote cell proliferation in the presence of p16INK4a and of hypophosphorylated retinoblastoma family proteins. Embo J 1997; 16:5322-33.

[57] Lukas J, Herzinger T, Hansen K et al. Cyclin E-induced S phase without activation of the pRb/E2F pathway. Genes Dev 1997; 11:1479-92.

[58] Dimri GP, Nakanishi M, Desprez PY et al. Inhibition of E2F activity by the cyclin-dependent protein kinase inhibitor p21 in cells expressing or lacking a functional retinoblastoma protein. Mol Cell Biol 1996; 16:2987-97.

[59] Gu Y, Rosenblatt J, Morgan DO. Cell cycle regulation of CDK2 activity by phosphorylation of Thr160 and Tyr15. Embo J 1992; 11:3995-4005.

[60] Harper JW, Elledge SJ. The role of Cdk7 in CAK function, a retro-retrospective. Genes Dev 1998; 12: 285-9.

[61] Larochelle S, Pandur J, Fisher RP et al. Cdk7 is essential for mitosis and for in vivo Cdk-activating kinase activity. Genes Dev 1998; 12:370-81.

[62] Poon RY, Hunter T. Dephosphorylation of Cdk2 Thr160 by the cyclin-dependent kinase- interacting phosphatase KAP in the absence of cyclin. Science 1995; 270:90-3.

[63] Hoffmann I, Draetta G, Karsenti E. Activation of the phosphatase activity of human cdc25A by a cdk2cyclin E dependent phosphorylation at the G1/S transition. Embo J 1994; 13:4302-10.

[64] Galaktionov K, Chen X, Beach D. Cdc25 cell-cycle phosphatase as a target of c-myc. Nature 1996; 382: 511-7.

[65] Iavarone A, Massague J. Repression of the CDK activator Cdc25A and cell-cycle arrest by cytokine TGFbeta in cells lacking the CDK inhibitor p15. Nature 1997; 387:417-22.

[66] Iavarone A, Massague J. E2F and histone deacetylase mediate transforming growth factor beta repression of cdc25A during keratinocyte cell cycle arrest. Mol Cell Biol 1999; 19:916-22.

[67] Harper JW, Adami GR, Wei N et al. The p21 Cdk-interacting protein Cip1 is a potent inhibitor of G1 


\section{G1 phase of the mammalian cell cycle}

cyclin- dependent kinases. Cell 1993; 75:805-16.

[68] Zhang H, Hannon GJ, Beach D. p21-containing cyclin kinases exist in both active and inactive states. Genes Dev 1994; 8:1750-8.

[69] Fotedar R, Fitzgerald P, Rousselle T et al. p21 contains independent binding sites for cyclin and cdk2: both sites are required to inhibit cdk2 kinase activity. Oncogene 1996; 12:2155-64.

[70] el-Deiry WS, Tokino T, Velculescu VE et al. WAF1, a potential mediator of p53 tumor suppression. Cell 1993; 75:817-25.

[71] LaBaer J, Garrett MD, Stevenson LF et al. New functional activities for the p21 family of CDK inhibitors. Genes Dev 1997; 11:847-62.

[72] Cheng M, Olivier P, Diehl JA et al. The p21(Cip1) and p27(Kip1) CDK 'inhibitors' are essential activators of cyclin D-dependent kinases in murine fibroblasts. Embo J 1999; 18:1571-83.

[73] Parry D, Mahony D, Wills K et al. Cyclin D-CDK subunit arrangement is dependent on the availability of competing INK4 and p21 class inhibitors. Mol Cell Biol 1999; 19:1775-83.

[74] Hengst L, Gopfert U, Lashuel HA et al. Complete inhibition of Cdk/cyclin by one molecule of p21(Cip1). Genes Dev 1998; 12:3882-8.

[75] Polyak K, Lee MH, Erdjument-Bromage H et al. Cloning of p27Kip1, a cyclin-dependent kinase inhibitor and a potential mediator of extracellular antimitogenic signals. Cell 1994; 78:59-66.

[76] Toyoshima H, Hunter T. p27, a novel inhibitor of G1 cyclin-Cdk protein kinase activity, is related to p21. Cell 1994; 78:67-74.

[77] Russo AA, Jeffrey PD, Patten AK et al. Crystal structure of the p27Kip1 cyclin-dependent-kinase inhibitor bound to the cyclin A-Cdk2 complex [see comments]. Nature 1996; 382:325-31.

[78] Shiyanov P, Hayes S, Chen N et al. p27Kip1 induces an accumulation of the repressor complexes of E2F and inhibits expression of the E2F-regulated genes. Mol Biol Cell 1997; 8:1815-27.

[79] Nakayama K, Ishida N, Shirane M et al. Mice lacking p27(Kip1) display increased body size, multiple organ hyperplasia, retinal dysplasia, and pituitary tumors. Cell 1996; 85:707-20.

[80] Kiyokawa H, Kineman RD, Manova-Todorova KO et al. Enhanced growth of mice lacking the cyclindependent kinase inhibitor function of p27(Kip1). Cell 1996; 85:721-32.

[81] Fero ML, Rivkin M, Tasch M et al. A syndrome of multiorgan hyperplasia with features of gigantism, tumorigenesis, and female sterility in p27(Kip1)-deficient mice. Cell 1996; 85:733-44.

[82] Coats S, Whyte P, Fero ML et al. A new pathway for mitogen-dependent cdk2 regulation uncovered in p27(Kip1)-deficient cells. Curr Biol 1999; 9:163-73.

[83] Durand B, Fero ML, Roberts JM et al. p27Kip1 alters the response of cells to mitogen and is part of a cell-intrinsic timer that arrests the cell cycle and initiates differentiation. Curr Biol 1998; 8:431-40.

[84] Ezhevsky SA, Toyoshima H, Hunter T et al. Role of cyclin A and p27 in anti-IgM induced G1 growth arrest of murine B-cell lymphomas. Mol Biol Cell 1996; 7:553-64.

[85] Kato JY, Matsuoka M, Polyak K et al. Cyclic AMP-induced G1 phase arrest mediated by an inhibitor (p27Kip1) of cyclin-dependent kinase 4 activation. Cell 1994; 79:487-96.

[86] Poon RY, Toyoshima H, Hunter T. Redistribution of the CDK inhibitor p27 between different cyclin. CDK complexes in the mouse fibroblast cell cycle and in cells arrested with lovastatin or ultraviolet irradiation. Mol Biol Cell 1995; 6:1197-213.

[87] Polyak K, Kato JY, Solomon MJ et al. p27Kip1, a cyclin-Cdk inhibitor, links transforming growth factorbeta and contact inhibition to cell cycle arrest. Genes Dev 1994; 8:9-22.

[88] Coats S, Flanagan WM, Nourse J et al. Requirement of p27Kip1 for restriction point control of the fibroblast cell cycle. Science 1996; 272:877-80.

[89] Orend G, Hunter T, Ruoslahti E. Cytoplasmic displacement of cyclin E-cdk2 inhibitors p21Cip1 and p27Kip1 in anchorage-independent cells. Oncogene 1998; 16:2575-83.

[90] Millard SS, Yan JS, Nguyen H et al. Enhanced ribosomal association of p27(Kip1) mRNA is a mechanism contributing to accumulation during growth arrest. J Biol Chem 1997; 272:7093-8.

[91] Hengst L, Reed SI. Translational control of p27Kip1 accumulation during the cell cycle. Science 1996; 


\section{Donjerkovic D and DW Scott}

271:1861-4.

[92] Pagano M, Tam SW, Theodoras AM et al. Role of the ubiquitin -proteasome pathway in regulating abundance of the cyclin-dependent kinase inhibitor p27 [see comments]. Science 1995; 269:682-5.

[93] Alessandrini A, Chiaur DS, Pagano M. Regulation of the cyclin-dependent kinase inhibitor p27 by degradation and phosphorylation. Leukemia 1997; 11:342-5.

[94] Sheaff RJ, Groudine M, Gordon M et al. Cyclin E-CDK2 is a regulator of p27Kip1. Genes Dev 1997; 11:1464-78.

[95] Vlach J, Hennecke S, Amati B. Phosphorylation-dependent degradation of the cyclin-dependent kinase inhibitor p27. Embo J 1997; 16:5334-44.

[96] Morisaki H, Fujimoto A, Ando A et al. Cell cycle-dependent phosphorylation of p27 c yclin-dependent kinase (Cdk) inhibitor by cyclin E/Cdk2. Biochem Biophys Res Commun 1997; 240:386-90.

[97] Muller D, Bouchard C, Rudolph B et al. Cdk2- dependent phosphorylation of p27 facilitates its Mycinduced release from cyclin E/cdk2 complexes. Oncogene 1997; 15:2561-76.

[98] Montagnoli A, Fiore F, Eytan E et al. U biquitination of p27 is regulated by Cdk-dependent phosphorylation and trimeric complex formation. Genes Dev 1999; 13:1181-9.

[99] An B, Goldfarb RH, Siman R et al. Novel dipeptidyl proteasome inhibitors overcome Bcl-2 protective function and selectively accumulate the cyclin-dependent kinase inhibitor p27 and induce apoptosis in transformed, but not normal, human fibroblasts. Cell Death Differ 1998; 5:1062-75.

[100] Scheffner M. Moving protein heads for breakdown [news; comment]. Nature 1999; 398:103-4.

[101] Tomoda K, Kubota Y, Kato J. Degradation of the cyclin-dependent-kinase inhibitor p27Kip1 is instigated by Jab1 [see comments]. Nature 1999; 398:160-5.

[102] Levkau B, Koyama H, Raines EW et al. Cleavage of p21Cip1/Waf1 and p27Kip1 mediates apoptosis in endothelial cells through activation of Cdk2: role of a caspase cascade. Mol Cell 1998; 1:553-63.

[103] Kawada M, Yamagoe S, Murakami Y et al. Induction of p27Kip1 degradation and anchorage independence by Ras through the MAP kinase signaling pathway. Oncogene 1997; 15:629-37.

[104] Perez Roger I, Solomon DL, Sewing A et al. Myc activation of cyclin E/Cdk2 kinase involves induction of cyclin E gene transcription and inhibition of p27(Kip1) binding to newly formed complexes. Oncogene 1997; 14:2373-81.

[105] Pusch O, Bernaschek G, Eilers M et al. Activation of c-Myc uncouples DNA replication from activation of G1- cyclin-dependent kinases. Oncogene 1997; 15:649-56.

[106] Vlach J, Hennecke S, Alevizopoulos K et al. Growth arrest by the cyclin-dependent kinase inhibitor p27Kip1 is abrogated by c-Myc. Embo J 1996; 15:6595-604.

[107] Leone G, DeGregori J, Sears R et al. Myc and Ras collaborate in inducing accumulation of active cyclin E/Cdk2 and E2F [published erratum appears in Nature 1997 Jun 26; 387(6636):932]. Nature 1997; 387:422-6.

[108] Nass SJ, Dickson RB. Epidermal growth factor-dependent cell cycle progression is altered in mammary epithelial cells that overexpress c-myc. Clin Cancer Res 1998; 4:1813-22.

[109] Mateyak MK, Obaya AJ, Sedivy JM. c-Myc regulates cyclin D-Cdk4 and -Cdk6 activity but affects cell cycle progression at multiple independent points. Mol Cell Biol 1999; 19:4672-83.

[110] Heckford SE, Gelmann EP, Agnor CL et al. Distinct signals are required for proliferation and lymphokine gene expression in murine T cell clones. J Immunol 1986; 137:3652-63.

[111] Nourse J, Firpo E, Flanagan WM et al. Interleukin-2-mediated elimination of the p27Kip1 cyclindependent kinase inhibitor prevented by rapamycin. Nature 1994; 372:570-3.

[112] Scott DW, Lamers M, Kohler G et al. Role of c-myc and CD45 in spontaneous and anti-receptor-induced apoptosis in adult murine B cells. Int Immunol 1996; 8:1375-85.

[113] Solvason N, Wu WW, Kabra N et al. Induction of cell cycle regulatory proteins in anti-immunoglobulinstimulated mature B lymphocytes. J Exp Med 1996; 184:407-17.

[114] Donjerkovic D, Zhang L, Scott DW. Regulation of p27Kip1 accumulation in murine B-lymphoma cells: role of c-Myc and calcium. Cell Growth Differ 1999; 10:695-704. 


\section{G1 phase of the mammalian cell cycle}

[115] Fero ML, Randel E, Gurley KE et al. The murine gene p27Kip1 is haplo-insufficient for tumour suppression. Nature 1998; 396:177-80.

[116] Tsihlias J, Kapusta L, Slingerland J. The prognostic significance of altered cyclin-dependent kinase inhibitors in human cancer. Annu Rev Med 1999; 50:401-23.

[117] Lloyd RV, Erickson LA, Jin L et al. p27kip1: a multifunctional cyclin-dependent kinase inhibitor with prognostic significance in human cancers. Am J Pathol 1999; 154:313-23.

[118] Fredersdorf S, Burns J, Milne AM et al. High level expression of p27(kip1) and cyclin D1 in some human breast cancer cells: inverse correlation between the expression of p27(kip1) and degree of malignancy in human breast and colorectal cancers. Proc Natl Acad Sci USA 1997; 94:6380-5.

[119] Tsihlias J, Kapusta LR, DeBoer G et al. Loss of cyclin-dependent kinase inhibitor p27Kip1 is a novel prognostic factor in localized human prostate adenocarcinoma. Cancer Res 1998; 58:542-8.

[120] Matsuoka S, Edwards MC, Bai C et al. p57KIP2, a structurally distinct member of the p21CIP1 Cdk inhibitor family, is a candidate tumor suppressor gene. Genes Dev 1995; 9:650-62.

[121] Zhang P, Liegeois NJ, Wong C et al. Altered cell differentiation and proliferation in mice lacking p57KIP2 indicates a role in Beckwith-Wiedemann syndrome. Nature 1997; 387:151-8.

[122] Cost GJ, Thompson JS, Reichard BA et al. Lack of imprinting of three human cyclin-dependent kinase inhibitor genes. Cancer Res 1997; 57:926-9. 